\title{
Comparison of the specificity of PCR and the histopathological detection of leishmania for the diagnosis of American cutaneous leishmaniasis
}

A.C.R. Medeiros,

S.S. Rodrigues and

A.M.F. Roselino

\author{
Laboratório de Biologia Molecular, Divisão de Dermatologia, \\ Departamento de Clínica M édica, Faculdade de Medicina de Ribeirão Preto, \\ Universidade de São Paulo, Ribeirão Preto, SP, Brasil
}

\section{Correspondence \\ A.M.F. Roselino \\ Divisão de Dermatologia \\ Departamento de Clínica M édica \\ FMRP, USP \\ Av. Bandeirantes, 3900 \\ 14049-900 Ribeirão Preto, SP \\ Brasil \\ Fax: + 55-16-633-6695 \\ E-mail: amfrosel@fmrp.usp.br}

Publication supported by FAPESP.

Received July 17, 2001

Accepted February 15, 2002

\section{Abstract}

More precise and rapid diagnostic methods for American cutaneous leishmaniasis (ACL) are necessary because of the growing number of cases observed in Brazil, including the northeastern region of the State of São Paulo. We applied PCR to 54 skin or mucosal biopsies from patients with a clinical and/or laboratory diagnosis of ACL using primers $13 \mathrm{~A}$ and $13 \mathrm{~B}$, with positive results being obtained for $82 \%$ of the samples. When the PCR results were compared to those of histopathological leishmania detection, PCR showed superior results with $81.5 \%$ sensitivity and $95 \%$ CI of $68.0-95.1 \%$. The Montenegro skin test (MST) was positive in $88.7 \%$ of patients. Since MST cannot be used as a diagnostic tool in endemic areas, the present results strongly suggest the use of PCR for the etiological confirmation of ACL, with emphasis on the mucosal form.
Leishmaniasis is one of the infectiousparasitic diseases of highest incidence in the world. According to the WHO, more than 12 million people in 88 countries are affected by the disease, and about 350 million more are at risk to contract it. The annual incidence is estimated at 1-1.5 million cases of cutaneous leishmaniasis and 500,000 cases of the visceral form. A growing number of cases of cutaneous leishmaniasis have been observed in Brazil, including the northeastern region of the State of São Paulo (1).

American cutaneous leishmaniasis (ACL) is defined as a noncontagious chronic disease characterized by the involvement of

\section{Introduction}

- Leishmaniasis

- Cutaneous leishmaniasis

- PCR

- Histopathological detection

- Leishmania detection

\section{Key words}

skin, mucosae and cartilages. In the Americas, it is caused by the Leishmania braziliensis and L. mexicana complexes. The diagnosis of ACL has been mainly clinical, especially in endemic areas. A definitive laboratory diagnosis is difficult to obtain since the detection of the parasite in the lesion becomes more remote as the disease becomes chronic (1).

New simpler methods of high sensitivity and specificity are being developed for the diagnosis and therapeutic follow-up of affected subjects and that can be applied to taxonomic diagnosis. The polymerase chain reaction (PCR) represents a new option among them (2-5). PCR has been shown to be highly sensitive for the diagnosis of ACL, 
with rapid detection of leishmania (6-11). PCR can also be used for the typing of leishmania isolated from clinical material, insect vectors, reservoirs, or culture media $(12,13)$. The method showed $98.40 \%$ sensitivity and $95.59 \%$ specificity for the diagnosis of individuals from the municipality of Caratinga, Minas Gerais (14).

In the present study we used PCR for the diagnosis of leishmaniasis in skin samples and compared it to the detection of the parasite by histopathological examination.

\section{Material and Methods}

The patients in the study and control groups had been seen at the University Hospital, Faculty of Medicine of Ribeirão Preto, University of São Paulo, Brazil.

\section{Skin and/or mucosal biopsy}

Biopsies of a cutaneous and/or mucosal lesion were obtained in duplicate from 54 patients with $A C L$ and stored at $-70^{\circ} \mathrm{C}$ for PCR and for fixation in formalin for histopathology. Control biopsies were obtained from the skin of 16 patients with a diagnostic suspicion of other dermatoses such as leprosy, cutaneous tuberculosis, squamous cell carcinoma, or nonspecific ulcers. The samples from ACL and control subjects were numbered in the order in which the patients were attended to, with no identification. Thus, the results of PCR were analyzed a posteriori and correlated to the results of clinical investigation.

Table 1. Comparison of the PCR results and the histopathological detection of leishmania in 54 cases of American cutaneous leishmaniasis.

\begin{tabular}{lccc}
\hline $\begin{array}{l}\text { Detection of } \\
\text { leishmania }\end{array}$ & \multicolumn{3}{c}{ PCR } \\
\cline { 2 - 4 } & Positive & Negative & Total \\
\hline Positive & 22 & 5 & 27 \\
Negative & 22 & 5 & 27 \\
Total & 44 & 10 & 54
\end{tabular}

\section{Histopathological study}

Skin and mucosal sections were stained with hematoxylin-eosin and examined for inflammatory infiltrates consisting of eosinophils, plasmocytes and/or granulomas and for the presence of intracytoplasmic corpuscles suggestive of leishmania.

\section{Polymerase chain reaction}

Primers 13A (5' GTG GGG GAG GGG CGT TCT $3^{\prime}$ ) and 13B (5' ATT TTA CAC CAA CCC CCA GTT 3') (Bio-Synthesis, http://www.biosyn.com) of the conserved region of the kDNA minicircle ( $\mathrm{k}=$ kinetoplast) of L. mexicana, strain PH8.4, were used (4). The method consisted of 25 cycles, $93^{\circ} \mathrm{C}(30 \mathrm{~s}), 60^{\circ} \mathrm{C}(1 \mathrm{~min}), 72^{\circ} \mathrm{C}(1 \mathrm{~min})$, preceded by initial denaturation for $3 \mathrm{~min}$ and $30 \mathrm{~s}$ at $94^{\circ} \mathrm{C}$ and a final 10 min extension at $72^{\circ} \mathrm{C}$, ending at $4^{\circ} \mathrm{C}(3-5) . L$. $(\mathrm{V}$.) braziliensis and $L .(L$.) amazonensis maintained in culture were used as positive controls.

\section{Statistical analysis}

Data were analyzed statistically by the McNemar test for comparison of PCR and histopathological results.

\section{Results}

PCR was positive in 44 of the 54 samples (81.5\%). When the PCR results were compared to the presence of leishmania detected by histopathological examination (Table 1), the sensitivity of the method was found to be $81.5 \%(\mathrm{P}<0.01,95 \% \mathrm{CI}=68.0-95.1 \%)$.

When the PCR results were compared to the presence of granulomas detected by histopathology, 25 of the 44 PCR-positive samples (56.8\%) presented granulomas $(\mathrm{P}<0.01)$, and in 7 of 10 PCR-negative samples no granulomas were observed. When PCR was compared to the presence of plasmocytes, 26 of 44 PCR-positive samples presented plas- 
mocytes $(59.1 \%, \mathrm{P}<0.05)$ and 6 of $10 \mathrm{PCR}-$ negative samples did not. When PCR was compared to the presence of eosinophils, 5 of 44 PCR-positive samples showed eosinophils $(11.4 \%, \mathrm{P}<0.01)$ and 8 of 10 PCRnegative samples did not.

\section{Discussion}

In the present study, PCR using primers $13 \mathrm{~A}$ and $13 \mathrm{~B}$ was positive in $81.5 \%$ of cases, with $81.5 \%$ sensitivity compared to the presence of leishmania upon histopathological examination. Using primers MP1L and MP3H for $L$. (V.) peruviana and $L$. $(V$.) braziliensis, Lopez et al. (6) obtained 87.6\% positivity by PCR. De Brujin et al. (15), using primers $\mathrm{B} 1$ and $\mathrm{B} 2$ for the L. braziliensis complex, obtained $84.6 \%$ sensitivity for PCR compared to direct examination, culture, and hamster inoculation. Using primers $13 \mathrm{~A}$ and 13B, Rodríguez et al. (16) obtained $97.0 \%$ positivity for PCR, and Belli et al. (17), using primers $\mathrm{B} 1$ and $\mathrm{B} 2$ and $\mathrm{MP} 3 \mathrm{H}$ and MP1L, obtained $100 \%$ sensitivity and $100 \%$ specificity for PCR compared to direct examination of lesion scrapings.

The Montenegro skin test (MST) was positive in $88.7 \%$ of patients (data not reported). All the 10 patients with negative PCR results presented a positive MST. In 5 of these $(9.3 \%)$, leishmania was detected by histopathology, characterizing a false-negative PCR result.

It should be emphasized the positivity of PCR in 5 of the 6 mucosal samples in which histopathology had not shown the presence of leishmania, as well as the fact that MST had been negative in 2 of these cases.

It is difficult to provide values for the sensitivity and specificity of PCR because no gold standard test is available for the diagnosis of ACL. Thus, when we calculated the sensitivity of PCR, since specificity could not be calculated due to the small group studied, we used the presence of leishmania upon histopathological examination as the gold standard. PCR proved to be superior than the histopathological detection of leishmania for the diagnosis of ACL. Since MST cannot be used as a diagnostic tool in endemic areas, these results strongly suggest the use of PCR for the etiological confirmation of ACL, with emphasis on the mucosal form.

\section{References}

1. Medeiros ACR \& Roselino AMF (1999). Leishmaniose tegumentar americana: do histórico aos dias de hoje. Anais Brasileiros de Dermatologia, 74: 329-336.

2. Grevelink SA \& Lerner EA (1996). Leishmaniasis. J ournal of the American Academy of Dermatology, 34 (Part 1): 257-272.

3. Barker DC \& Butcher J (1983). The use of DNA probes in the identification of leishmanias: Discrimination between isolates of the Leishmania mexicana and L. braziliensis complexes. Memórias do Instituto Oswaldo Cruz, 77: 285-297.

4. Rodgers MR, Popper SJ \& Wirth DF (1990). Amplification of kinetoplast DNA as a tool in the detection and diagnosis of leishmania. Experimental Parasitology, 71: 267-275.
5. Blackwell J M (1992). Leishmaniasis epidemiology: all down to the DNA. Parasitology, 104: s19-s34.

6. Lopez M, Inga R, Cangalaya M, Echevarria J , Llanos-Cuentas A, Orrego C \& Arevalo J (1993). Diagnosis of leishmania using the polymerase chain reaction: a simplified procedure for field work. American J ournal of Tropical Medicine and Hygiene, 49: 348-356.

7. Ashford DA, Bozza M, Miralba F, Miranda J C, Sherlock I, Eulalio C, Lopes U, Fernandes O, Degrave W, Barker J r RH, Badaro R \& David J R (1995). Comparison of the polymerase chain reaction and serology for the detection of canine visceral leishmaniasis. American J ournal of Tropical Medicine and Hygiene, 53: 251-255.
8. Pirmez C, Trajano VS, Paes-Oliveira Neto M, Cruz AM, Costa SCG, Catanho M, Degrave W \& Fernandes O (1999). Use of PCR in diagnosis of human American tegumentary leishmaniasis in Rio de $J$ aneiro, Brazil. J ournal of Clinical Microbiology, 37: 1819-1823.

9. Grisard EC, Steindel M, Shaw JJ, Ishikawa EAY, Carvalho-Pinto CJ , Eger-Mangrich I, Toma HK, LimaJ H, Romanha AJ \& Campbell DA (2000). Characterization of Leishmania sp. strains isolated from autochthonous cases of human cutaneous leishmaniasis in Santa Catarina State, southern Brazil. Acta Tropica, 74: 89-93.

10. Brecelj M, Pikelj F, Gubensek F \& Anderluh $G$ (2000). Polymerase chain reaction as a diagnostic tool for detecting 
leishmania. Infection, 28: 111-113.

11. Delgado O, Guevara P, Silva S, Belford E \& Ramirez J L (1996). Follow-up of human accidental infection by Leishmania (Viannia) braziliensis using conventional immunologic techniques and polymerase chain reaction. American J ournal of Tropical Medicine and Hygiene, 55: 267-272.

12. Degrave $W$, Fernandes $O$, Campbell $D$, Bozza M \& Lopes U (1994). Use of molecular probes and PCR for detection and typing of leishmania: a mini-review. Memórias do Instituto Oswaldo Cruz, 89: 463-469.

13. Medeiros ACR, Rodrigues SS \& Roselino
AMF (2001). Otimização da tipagem de L. (V.) braziliensis e L. mexicana amazonensis por PCR. Jornal Brasileiro de Patologia, 37: 88 (Abstract).

14. Gontijo B (1998). A reação em cadeia da polimerase (PCR) no diagnóstico da leishmaniose tegumentar americana. Doctoral thesis, Departamento de Clínica Médica, Universidade Federal de Minas Gerais, Belo Horizonte, MG, Brazil.

15. De Brujin MHL, Labrada LA, Smyth AJ, Santrich C \& Barker DC (1993). A comparative study of diagnosis by the polymerase chain reaction and by current clinical methods using biopsies from Colom- bian patients with suspected leishmaniasis. Tropical Medicine and Parasitology, 44: 201-207.

16. Rodríguez N, Guzman B, Rodas A, Takiff H, Bloom BR \& ConvitJ (1994). Diagnosis of cutaneous leishmaniasis and species discrimination of parasites by PCR and hybridization. J ournal of Clinical Microbiology, 32: 2246-2252.

17. Belli A, Rodriguez B, Aviles H \& Harris E (1998). Simplified polymerase chain reaction detection of new world leishmania in clinical specimens of cutaneous leishmaniasis. American J ournal of Tropical Medicine and Hygiene, 58: 102-109. 